\title{
FEMINISME PADA NOVEL CINTA SUCI ZAHRANA KARYA HABIBURRAHMAN EL SHIRAZY
}

\author{
Andestend \\ Universitas Ibn Khaldun Bogor, Indonesia \\ andestend3@gmail.com
}

Accepted: 2020-11-27, Approved: 2020-12-25 , Published: 2020-01-18

\begin{abstract}
ABSTRAK
Karya sastra memang menjadi wadah bagi para penulis untuk mencurahkan pandangan, pendapat, kritikan, dan hal lainnya dalam bentuk sebuah karya sastra. Karya sastra memiliki gaya penulisan dan pandangan masing-masing salah satunya Feminisme. Feminisme memang menjadi kajian yang menarik oleh berbagai kalangan. Penelitian ini membahas tentang ide feminisme pada novel Cinta Suci Zahrana karya Habiburrahman El Shirazy. Metode penelitian kualitatif dengan studi pustaka jadi tidak terikat oleh tempat penelitian. Hasilnya ditemukan ide feminisme di dalam novel Cinta Suci Zahrana, dibuktikan dengan menuntut kesamaan derajat antara laki-laki dengan perempuan. Salah satu bukti autentik di dalam novel ketika Zahrana ingin sekolah tinggi karena dengan sekolah yang tinggi maka perempuan dapat menyetarakan kedudukan laki-laki, sehingga Zahrana lupa dengan usia yang sudah lanjut sewajarnya usia 35 tahun itu perempuan sudah menikah dan menjadi seorang Ibu.
\end{abstract}

Kata kunci: sastra, novel, ide feminisme

\section{PENDAHULUAN}

Konsekuensi pandangan ini adalah bahwa dunia diciptakan sastrawan dalam puisi, novel, dan drama merupakan hasil khayalan yang harus dipisahkan dari dunia nyata, yakni dunia yang kita hayati seharihari ini. Salah satu bentuk karya sastra yang banyak digemari oleh pembaca adalah novel. Hal ini dapat dilihat dari perkembangan novel di Indonesia sekarang cukup pesat, terbukti dengan banyaknya novel-novel baru telah diterbitkan. Novel tersebut mempunyai bermacam tema dan isi, antara lain tentang problem-problem sosial yang pada umumnya terjadi dalam masyarakat, termasuk yang berhubungan dengan wanita, sosok wanita sangat menarik untuk dibicarakan, wanita cenderung dimanfaatkan oleh kaum lakilaki untuk memuaskan anggotanya. Wanita telah menjelma menjadi bahan eksploitasi bisnis dan seks. Dengan kata lain, saat ini telah hilang sifat feminisme yang dibanggakan dan disanjung bukan saja oleh wanita, tetapi juga kaum laki-laki.

Mary Wollstonecraft, feminisme pertama yang mengatakan adanya pembodohan terhadap perempuan yang disebabkan tradisi masyarakat yang menjadikan perempuan sebagai makhluk yang tersubordinasi. Abad ke-20 (1949) lahir karya Simone De Beauvoir "le deuxieme sexe", ditemukan istilah kesetaraan. tahun 1960an: mulai menggunakan istilah penindasan dan pembebasan. Tahun 60-70an: membawa perubahan sosial yang luar biasa di dunia barat (lahirnya undang-undang yang menguntungkan perempuan), konsep patriarki mulai mengemuka. Tahun 7080an: wacana feminisme bermunculan di Amerika Latin, Asia, dan di negara-negara dunia ketiga pada umumnya, (Sauer, 2017). 
Feminisme adalah gerakan

sosial, gerakan politik, dan ideologi yang memiliki tujuan yang sama, yaitu untuk mendefinisikan, membangun, dan mencapai kesetaraan gender di lingkup politik, ekonomi, pribadi, dan sosial. Feminisme menggabungkan posisi bahwa masyarakat memprioritaskan sudut pandang laki-laki, dan bahwa perempuan diperlakukan secara tidak adil di dalam masyarakat tersebut. Upaya untuk mengubahnya termasuk dalam memerangi stereotip gender serta berusaha membangun peluang pendidikan dan profesional yang setara dengan laki-laki, (Laura Brunell and Elinor Burkett, 2019).

Feminisme bukanlah perlawanan kepada kaum laki-laki, melainkan menuntut kesetaraan (patriarki) dalam kebebasan pendapat, pendidikan, politik, ekonomi, dan status sosial. Selama ini pemahaman di Indonesia yang keliru tentang feminisme karena yang dipahami adalah menentang kaum laki-laki, sehingga dengan penafsiran yang keliru membuat gejolak pada masyarakat yang belum memahami feminisme secara menyeluruh.

Dari berbagai pendapat tentang feminisme di atas telah banyak penelitian tentang ide feminisme di dalam karya sastra terutama dalam novel, penelitian yang pertama dilakukan oleh (Abidah et al., 2015) dengan judul Feminisme Dalam Novel Perempuan Berkalung Sorban Karya Abidah El Khalieqy Dan Kelayakannya hasilnya jenis aliran feminisme, novel Perempuan Berkalung Sorban dapat digolongkan sebagai salah satu novel beraliran feminisme radikal, jenis kritik feminisme, novel Perempuan Berkalung Sorban dapat digolongkan sebagai kritik feminis marxis/sosialis. (Ariesta \& Muliastuti1, 2017) melakukan analisis terhadap film The Help, melawan tiga bentuk penindasan yakni penindasan ras, kelas sosial dan gender. (Pertiwi, 2018) mengkaji dan menjelaskan keberadaan perempuan dan struktur novel
Hajar Sibel Eraslan berdasarkan literatur feminisme.

Selanjutnya penelitian yang dilakukan (Kurnia, 2013) dengan judul Kajian Feminisme Dalam Novel Secuil Hati Wanita Di Teluk Edenkarya Vanny Chrisma W. Dengan hasil 1) Bentuk tidak adil gender tokoh utama dalam novel Secuil Hati Wanita di Teluk Eden karya Vanny Chrisma W. berupa stereotipe (pelabelan negatif), kekerasan yang meliputi kekerasan domestik (kekerasan fisik dan kekerasan emosional), dan kekerasan publik. 2) Bentuk perjuangan tokoh utama untuk melawan penindasan dalam novel Secuil Hati Wanita di Teluk Eden karya Vanny Chrisma W. berupa pemberian pemahaman dan mengutarakan pendapat. Penelitian yang dilakukan oleh (Indayani, 2014) Feminisme Dalam Novel Bibir Merah Karya Achmad Munif. Penelitian (Nursida, 2015) Isu Gender Dan Sastra Feminis Dalam Karya Sastra Arab, dan masih banyak lagi penelitian tentang feminisme.

(Pertiwi, 2018) mengatakan bahwa struktur elemen bangunan yang terdapat dalam Hajar meliputi tema, penokohan, alur, dan latar; citra perempuan dalam Hajar yang meliputi citra fisik dan non fisik; dan peran perempuan dalam Hajar yang sesuai dengan peran domestik dan publik. (Ariesta \& Muliastuti1, 2017) mengatakan unsur fiksi yakni unsur intrinsik dalam film The Help karya Tate Taylor meliputi penokohan, tema, alur dan latar. Usaha-usaha yang dilakukan perempuan dalam menghadapi diskriminasi ras digambarkan dalam film The Help karya Tate Taylor berdasarkan unsur-unsur fiksi. Bentuk-bentuk perilaku diskriminasi ras yang digambarkan dalam film The Help karya Tate Taylor berdasarkan unsur-unsur fiksi. (Ade Husnul awadah, 2017) mengatakan dalam cerpen-cerpen dalam buku pelajaran bahasa Indonesia mengandung kesetaraan gender. Artinya bahwa aliran feminisme telah berkembang, bukan hanya pada novel 
atau cerpen melainkan sudah masuk ke dalam ranah buku ajar siswa. Untuk itulah pentingnya pemahaman yang mendalam tentang feminisme sehingga tidak menimbulkan kekeliruan dalam menafsirkan.

Berdasarkan uraian dan hasil penelitian di atas ada beberapa usur yang belum dibahas yaitu unsur feminisme patriarki di dalam karya sastra, kedua novel Cinta Suci Zahrana ini di tulis oleh Habiburrahman ia adalah seorang laki-laki, ketiga fenomena yang disajikan tentang kehidupan sosial tokoh feminisme di salam novel, maka fokus penelitian ini terhadap tiga hal tersebut, yaitu patriarki, penulis laki-laki, dan fenomena feminisme sosial pada novel Cinta Suci Zahrana Karya Habiburrahman El Shirazi.

\section{METODOLOGI}

Penelitian ini menggunakan pendekatan kualitatif. (Airasian, 2012) mengatakan penelitian kualitatif adalah pengumpulan, analisis, dan interpretasi narasi secara komprehensif pada data visual untuk mendapatkan wawasan terhadap fenomena tertentu yang menarik. Alasan dipergunakannya metode ini berkaitan dengan obyek yang akan diteliti yaitu masyarakat manusia (sosial). (Creswell, 2010) penelitian kualitatif adalah proses untuk memahami masalah sosial berdasarkan metodologi yang berbeda. Dalam hal ini, peneliti akan menyusun gambaran yang kompleks, menganalisis kata demi kata dan menyusun hasil penelitian secara natural/sesuai fakta di lapangan.

Penelitian ini penelitian kualitatif dengan studi pustaka jadi tidak terikat oleh tempat penelitian. Penelitian ini dilaksanakan pada bulan Juni 2019. Data penelitian ini adalah ide feminisme dalam novel Cinta Suci Zahrana karya Habiburrahman El Shirazy. Sumber data penelitian ini adalah novel Cinta Suci Zahrana karya Habiburrahman El Shirazy. Data adalah sebuah novel Cinta Suci
Zahrana karya Habiburrahman El Shirazy. Teknik pengumpulan data dilakukan dengan cara dokumentasi dan teknik catat. Teknik analisis data (1) membaca keseluruhan novel, (2) menandai dan mencatat kutipan pada novel, (3) mengklasifikasikan hasil temuan, (4) menganalisis hasil temuan sesuai dengan masalah penelitian, (5) langkah yang terakhir menyimpulkan.

\section{HASIL DAN PEMBAHASAN}

Nama Zahrana mendunia karena karya tulisnya dimuat di jurnal ilmiah RMIT Melbourne. Dari karya tulis itu, Zahrana meraih penghargaan dari Thinghua University, sebuah universitas ternama di China. Ia pun terbang ke negeri Tirai Bambu untuk menyampaikan orasi ilmiah. Di hadapan puluhan Profesor arsitek kelas dunia, ia memaparkan arsitektur bertema budaya. Yang ia tawarkan arsitektur model kerajaan JawaIslam dahulu kala. Dari Thinghua University, Zahrana mendapat tawaran beasiswa untuk studi S3 di samping mendapat tawaran pengerjaan sebuah proyek besar. Namun Zahrana tidak hidup sendiri. Di tengah kesuksesan prestasi akademiknya, ia malah menjadi bahan kecemasan kedua orang tuanya. Kecemasan itu lantaran Zahrana belum juga menikah di usianya yang memasuki kepala tiga. Sudah banyak laki-laki yang meminangnya, namun Zahrana menolaknya dengan halus.

Di sinilah konflik batin Zahrana mulai timbul, antara menuruti keinginan orang tua atau mengejar cita-cita. Sebenarnya Zahrana sudah mengalah. Ia tak menerima tawaran jadi dosen di UGM. Alasannya karena orang tuanya yang tinggal di Semarang tidak mau jauh. Zahrana pun memilih mengajar di sebuah universitas di Semarang. Ia tetap bisa tinggal bersama orang tuanya. Zahrana juga mengalah pada orang tuanya hingga ia tidak mengambil tawaran beasiswa S3 di negeri China. 
Meski tak otoriter, kedua orang tua Zahrana berharap anak satu-satunya itu segera menikah dan memiliki keturunan. Sebagai orang tua yang sudah renta, khawatir semasa hidupnya tidak sempat menyaksikan Zahrana bersuami dan menimang cucu. Apalagi bila melihat anak-anak tetangga seusia Zahrana, mereka sudah memiliki anak dua bahkan tiga. Sebenarnya dalam jiwa perempuan Zahrana, bukan tidak menghiraukan keinginan berumah tangga. Tetapi logika analitisnya selalu berargumen, menikah hanya menunda-nunda sukses bahkan bisa menghalanginya.

Puncak konflik batin Zahrana ketika dilamar oleh seorang duda yang notabene atasannya sendiri. Ia dilamar dekannya, begitu kembali dari Thinghua University sehabis menerima penghargaan. Dengan tegas, Zahrana tidak menerima lamaran atasannya itu meski orang tuanya kecewa. Alasan Zahrana semata-mata persoalan moral atasannya yang terkenal suka meminta setoran kepada mahasiswa bila ingin nilai bagus bahkan suka bermain cinta dengan mahasiswanya sendiri. Di samping alasan moral, Zahrana tak mungkin menerima lamaran atasannya yang berusia kepala lima. Akibat menolak lamaran itu, Zahrana akan dipecat secara tidak hormat. Tetapi Zahrana mendahului mengajukan pengunduran diri. Ia benarbenar hengkang dari kampus itu dan memilih mengajar di sebuah sekolah kejuruan teknik.

Pasca lamaran, Zahrana sadar, ia harus cepat-cepat bersuami. Hati Zahrana berargumen lain bisa saja dirinya melanjutkan cita-cita di dunia akademik meski sudah bersuami. Ia pun minta saran kepada pimpinan pondok pesantren yang masih saudara jauh teman akrabnya. Oleh pimpinan pondok pesantren Zahrana dipertemukan seorang pemuda yang dari sisi pekerjaan kurang prestisius. Pemuda itu pedagang kerupuk keliling dan Zahrana merasa cocok. Ia bertekad mengabdikan hidupnya kepada Allah melalui ibadah dalam rumah tangga. Kedua belah keluarga menyiapkan pesta pernikahan sederhana. Zahrana menyiapkan gaun pengantin. Bahagia sekali hati Zahrana. Ia meyakinkan diri tak lama lagi akan bersuami yang saleh. Ia membayangkan esok hari, kisah penantian ini akan segera berganti.

Namun bayangan itu sirna seketika saat menerima kabar calon suaminya meninggal, tertabrak Kereta Api yang tak jauh dari perkampungan. Saat itu pula Zahrana merasa sudah mati. Bayangan indah kini berganti dengan kabut tebal yang dipenuhi hantu kematian yang siap mencabik-cabik dirinya. Bunga-bunga cinta di hatinya, kini berganti dengan bunga kematian. Langit pun runtuh dan serasa menindihnya. Zahrana pingsan beberapa kali hingga dilarikan ke rumah sakit. Beruntung Zahrana masih kuat melanjutkan hidup.

Beberapa hari pasca tragedi, ia hanya di rumah sambil menekuri diri. Sahabat-sahabat dan kerabatnya banyak yang berdatangan untuk sekedar mengucapkan duka cita termasuk temanteman dan atasannya di kampus dulu mengajar. Salah seorang menjenguk, dokter perempuan yang sempat mengobatinya di rumah sakit. Perempuan itu ternyata ibunya mahasiswa bernama Hasan yang skripsinya sempat dia bimbing. Rupanya kedatangan ibu dokter ini sekaligus mengobati luka cinta Zahrana.

Ibu dokter ternyata mengabarkan, anaknya, Hasan, berniat menikahinya. Betapa kaget dan bahagianya Zahrana. Seolah tak peracaya dengan nasibnya yang begitu bergelombang. Meski ragu menerima lamaran itu, Zahrana menyampaikan satu syarat. Bila anak ibu dokter benar meminangnya, ia minta agar pernikahannya nanti malam setelah salat tarawih. Ia sangat trauma dengan tragedi yang menimpa satu malam menjelang pernikahannya dulu. Setelah dialog cukup panjang, tawaran itu diterima ibu dokter. 
Tepat jam tujuh malam, mereka melangsungkan pernikahan suci di masjid yang disaksikan para jamaah salat tarawih. Malam pertama bulan Ramadhan yang indah menandakan berakhirnya penderitaan Zahrana. Ia menyempurnakan hidupnya dengan mencurahkan cinta sucinya.

Dalam novel ini dapat dilihat ide feminisme ketika Zahrana ingin sekolah yang lebih tinggi karena ia berpandangan dengan sekolah tinggi maka derajat wanita akan naik dan setara dengan laki-laki, disisi lain Zahrana menunda pernikahan padahal usianya sudah lanjut, ia berpendapat bahwa dengan menikah akan menghalangi semua kegiatannya dan menunda keberhasilan. Dilihat dari Zahrana menunda pernikahan padahal usianya sudah cukup matang untuk menjalankan rumah tangga berarti Zahrana ini tidak memiliki jiwa keibuan.

Feminisme merupakan suatu konsep yang menggambarkan tentang kesetaraan antara kaum perempuan dan laki-laki dalam bidang pendidikan, sosial politik, dan ekonomi. Dengan demikian feminisme berkenaan dengan hak-hak perempuan dalam lingkungan sosial. Kaum feminisme menganggap bahwa selama ini perempuan selalu diasingkan oleh masyarakat yang menganut patriarki.

Novel Cinta Suci Zahrana karya Habiburrahman El Shirazy ini merupakan kisah seorang perempuan yang berjuang untuk mendapatkan cinta sejatinya serta berjuang meraih cita-cita yang dia impikan. Novel Cinta Suci Zahrana ini mempunyai ide feminisme karena terlihat dari karakter tokoh utama yaitu Zahrana yang bersifat ingin kebebasan dan menuntut kesamaan derajat dengan lakilaki yang dilakukan Zahrana dalam bidang intelektual (pendidikan).

Analisis feminisme eksistensialis dalam novel Cinta Suci Zahrana karya Habiburrahman El Shirazy, menekankan pada kebebasan seseorang terutama perempuan dalam menentukan arah dan tujuan hidupnya tanpa harus mendapatkan tekanan dan paksaan dari pihak yang lain. Perempuan yang sadar akan kebebasannya dapat dengan leluasa menentukan jalan hidupnya, sehingga perempuan dapat pergi bekerja dan mengaktualisasikan diri secara maksimal. Perempuan bisa menjadi intelektual dan tidak perlu khawatir akan kemampuannya jika dilihat dari keterbatasan biologisnya. Perempuan juga harus dapat menolak dijadikan objek dan bisa mengobjekkan laki-laki.

Zahrana sangat menjunjung tinggi pendidikan dan memiliki banyak prestasi bahkan prestasi dari luar negeri, karena yang dia pikirkan hanya belajar dan belajar dan tidak menghiraukan masalah pribadi terutama masalah cinta dan berumah tangga. Pendidikan memang dapat mengangkat harkat dan martabat semua orang untuk itu baik perempuan atau lakilaki sama-sama di wajibkan untuk mengecap pendidikan yang lebih tinggi. Dengan pendidikan yang tinggi seseorang bisa lebih terhormat apa dia seorang perempuan atau laki-laki dengan pendidikanlah kita bisa maju dan tidak di rendahkan orang lain. Sesuai dengan pendapat R.A. Kartini, pendidikan merupakan sarana untuk meningkatkan kedudukan kaum perempuan.

Selain itu juga, Zahrana menyorotkan tentang perempuan zaman sekarang. Tidak zamannya lagi kalau perempuan itu diatur oleh adat dan normanorma yang tidak ada patokan ilmiahnya, perempuan itu mampu maju dan mengembangkan potensi yang dimilikinya. Perempuan itu lemah karena dia tidak intelektual dan selalu berpegang pada nilai tradisional yang berlaku dalam lingkungan masyarakat tersebut, sehingga membuatnya terbelenggu dengan adat dan norma yang berlaku dalam lingkungan tempat tinggal. Sesuai dengan pendapat Fakih, keterbelakangan dan ketidakmampuan kaum perempuan bersaing dengan laki-laki adalah karena kelemahannya sendiri, yaitu akibat dari 
kebodohan dan sikap irasional yang berpegang teguh kepada nilai-nilai tradisional. Di dalam lingkungan tempat tinggal perempuan tentu ada juga laki-laki.

Aliran yang dominan dianut oleh tokoh feminisme: Zahrana, Lina, dan Hasan adalah aliran feminisme liberal yaitu perempuan yang menuntut kebebasan dan kesamaan yang berakar pada rasional (intelektual). Dan menurut aliran ini akar dari ketertindasan dan keterbelakangan perempuan disebabkan oleh perempuan itu sendiri. Perempuan harus mempersiapkan diri agar bisa bersaing di dunia dalam rangka "persaingan bebas" dan mempunyai kedudukan setara dengan lakilaki.

Sedangkan Orang tua Zahrana, Pak Munajat (Ayah Zahrana), Bu Nuriyah (Ibu Zahrana). Pendapat mereka bila dicermati terdapat prasangka gender. Ia menginginkan perlakuan yang sebaikbaiknya terhadap perempuan, tetapi di sisi lain ia tetap mengurung perempuan dalam "sangkar emas" rumah tangga. begitu juga dengan pandangan Islam. Islam memberikan perempuan hak-hak kemanusiaannya, individualitasnya, kebebasannya, dan kemerdekaannya, tetapi Islam tidak pernah berlaku seperti orang Barat yang menghasut perempuan yang memberontak atau bersikap sinis terhadap laki-laki. Gerakan perempuan Islam tidak menyingkirkan penghormatan seorang putri kepada ayahnya dan penghormatan istri pada suaminya. Dasar-dasar kehidupan keluarga tidak dirusak. Gerakan ini tidak membuat perempuan tidak suka bersuami, tidak suka menjadi ibu, tidak suka membesarkan anak. Gerakan ini pun tidak membiarkan perempuan menyerahkan kehormatannya kepada lakilaki bergelar dan berharta.

\section{KESIMPULAN}

Novel Novel Cinta Suci Zahrana
Karya Habiburrahman El Shirazy
menganut ide feminisme dengan prinsip
patriarki menuntut kesamaan derajat antara

laki-laki dan perempuan terlihat ketika Zahrana ingin sekolah tinggi, karena dengan sekolah yang tinggi maka perempuan dapat menyamakan kedudukan laki-laki, sehingga Zahrana lupa dengan usia yang sudah lanjut sewajarnya usia 35 tahun itu perempuan sudah menikah dan menjadi seorang Ibu. Kemudian di dalam novel ini mendeskripsikan karakter tokoh feminisme walaupun pengarangnya adalah seorang laki-laki. Dari novel ini menggambarkan juga feminisme sosial masyarakat dalam suatu budaya tertentu perempuan tidak boleh menduduki tempat yang strategis, seperti pemimpin, mengambil keputusan, sekolah dan lainlain.

\section{DAFTAR PUSTAKA}

Abidah, K., Khalieqy, E. L., Kelayakannya, D. A. N., \& Fuad, M. (2015). J-Simbol (Bahasa, Sastra, dan Pembelajarannya) Juni 2015. JSimbol (Bahasa, Sastra, Dan Pembelajarannya), 1-9.

Ade Husnul awadah. (2017). Kesetaraan Gender pada Cerpen-Cerpen dalam Buku Pelajaran Bahasa Indonesia: Analisis Isi. BAHTERA: Jurnal Pendidikan Bahasa Dan Sastra, vol 16 no, 12.

Airasian, L. R. G. G. E. M. P. W. (2012). Educational Research Competencies For Analysis and Applications. Pearson.

Ariesta, F., \& Muliastuti1, L. (2017). Diskriminasi Ras Dalam Film The Help Karya Tate Taylor (Kajian Feminisme). BAHTERA: Jurnal Pendidikan Bahasa Dan Sastra, 16(2), 47-55. https://doi.org/10.21009/bahtera.162. 04

Creswell, J. W. (2010). Research Design Pendekatan Kualitatif, Kuantitatif, dan Mixed (edisi keti). Pustaka Pelajar.

El Shirazy, H. (2011). Cinta Suci Zahrana. Jakarta: PT. Balai Pustaka. 
Indayani. (2014). Feminisme Dalam Novel Bibir Merah. Jurnal Buana Bastra, 1, $31-42$.

Kurnia, I. (2013). Kajian Feminisme dalam Novel Secuil Hati Wanita di Teluk Eden Karya Vanny Chrisma W. Jurnal Pendidikan Dan Pembelajaran, 2(7), 11. http://jurnal.untan.ac.id/index.php/jpd $\mathrm{pb} /$ article/view/2376

Laura Brunell and Elinor Burkett. (2019). Feminism, the belief in social, economic, and political equality of the sexes. In Encyclopaedia Britannica.
Nursida, I. (2015). Isu Gender Dan Sastra Feminis Dalam Karya Sastra Arab: Alfaz (Vol.3 No.1 [Januari-Juni] 2015 ISSN: 2339-2882).

Pertiwi, E. M. (2018). Women's Existence In Sibel Eraslan's Hajar (A Feminism Study). Journal of Chemical Information and Modeling, 53(9), 1689-1699.

Sauer, E. (2017). The Postcolonial Critic. In South Asian Review (Vol. 30, Issue 2). https://doi.org/10.1080/02759527.200 9.11932679 